\title{
Draft of Loan Transactional Paper between Vegetables Traders and "Bank Plecit" in a Traditional Market of Purwokerto
}

\author{
Ratna Kartikawati \\ Universitas Muhammadiyah Purwokerto \\ ratnakartikawati@yahoo.co.id
}

\begin{abstract}
The purpose of this research was to analyze the transaction process of savings and loans between green-grocers and plecit (small-scale) banks in a traditional market, Wage Market, in Purwokerto, to identify the role of plecit banks in the transactions, and to examine the draft deed of the transactions which will provide a legal protection. This was a qualitative research employing a case study research design with a Juridical Sociological Approach. It was appropriate to examine the problems in society from a perspective of law. The target of this research was legal norms and behavior patterns. The bond of the green-grocers to the banks was due to their easy procedure, the fast process of loan cashing, no collateral and no sanctions of late payment. These small banks were needed by the people in the situation in which formal financial institutions applied a complex credit selection. These banks became a practical solution for them with their easy credit allowance; although they put much higher interest. Providing a draft deed of savings and loan transactions would establish a legal protection for the people; the contract would inform clearly the rights and obligations between the parties involved, i.e. the creditors and the debtors.
\end{abstract}

Keywords: vegetable traders, bank plecit

\section{INTRODUCTION}

Most of the customers of Plecit (a small-scale bank usually run by an individual to earn high interest from the loans they provide) in traditional markets are small traders. The peddlers are commonly engaged in an informal sector and small scale business. They are usually poor or near poor.

Rationally human beings will choose an efficient [1]. [2] that in economic matters, human beings have a tendency "to pay the lowest possible cost to gain the maximum profit." In the context of getting a loan, normally a person will prefer to borrow at a low cost. However, the peddlers in the traditional markets choose to get the loans from high-interest loan scheme provided by plecit banks. In fact, many formal financial institutions have provided them with loan schemes with lower (interest) cost.
This situation can be seen in a traditional market in a small town of Purwokerto. Here, there are many formal financial institutions in the form of creditors, cooperatives, and pawnshops. But they have a problem with a credit access. This is not surprising especially in less developed economic conditions where small to medium enterprises have limited access to a credit [3]. Moreover, they do not have any access to formal financial institutions because of lack of collateral. The poor are often excluded from formal credits [4], partially due to the lack of collaterals or guarantors [5]. In the market, called as Wage Market, there is a financial dualism, between Plecit bank as an informal financial institution and a formal financial institution such as cooperatives, credits and pawnshops. They build their business by managing a high-interest loan, up to $40 \%$ ), which is very detrimental to traders.

The major obstruction faced by the traders in developing their business is the hardship of gaining credit because of the collateral inexistence resulting in the condition that they have to take the loan with high interest rate from plecit banks. [6] the weakness of small and micro enterprises related to the five $\mathrm{C}$ of credit analysis is in respect of collateral. The application of loan is refused by the creditor because it is worthless for creditor to give a loan to numbers of micro and small enterprises including the green-grocers who do not have any collateral.

Meanwhile, the head of traders' coaching section of Wage market management office said that direct socialization coaching to the traders has been carried out by the officials annualy dealing with the locating and arrangement of the traders including the prevention from plecit bank practice. As a matter of fact, the traders getting ensnared by plecit banks are numerous. The problem is that the traders do not need to be bothered by various requirements in order to be able to get a loan from plecit banks. Consequently, many traders choose to borrow money from plecit banks although they get higher interest. A moneylender is a person who lends money at excessively high rates of interest. The moneylender is called a loan shark. The reality shows that a moneylender is still an important capital source for merchants [7]. When viewed from the practice, the green-grocers taking the loan from the banks are aggrieved because they are given very high interest rates ranging from $20 \%$ to $40 \%$, moreover, they do not have 
any legal protection in case of disputes in the transaction because there is no deed of agreement which provides a legal protection for them. As a result, whether the incumbency between plecit banks and the borrowers is fair or not is not realized by them. They even do not find out what percentage of the interest applied by the plecit banks on the loan because they pay in installments daily as requested by the plecit banks.

Based on the above explanation, the research problem can be formulated as follows:

1. How is the process of implementation of savings and loan transaction between the green-grocers and plecit banks in Wage Market Purwokerto?

2. What is the role of plecit banks in the saving and loan transactions in Wage Market Purwokerto?

3. Can the draft of the saving and loan transaction deed between the green-grocers and the plecit banks in Wage Market Purwokerto provide the legal protection?

\section{METHODS}

This was a qualitative research employing a case study research design with a Juridical Sociological Approach. It is appropriate to examine the problems in the society from the law perspective. The target of this research was legal norms and behavior patterns.

Research Subjects

The subjects of this research were the traders in Wage Market in Purwokerto. The Sampling technique used was purposive sampling technique.

Methods and Instruments of Data Collection

In collecting the data, the researcher employed the following methods:

A guided interview technique with the green-grocers and plecit banks and the head of traders' coaching section in Wage was done in order to find out the implementation of saving and loan transactions with plecit banks.

An observation was conducted from the beginning of the study by observing the physical condition of the environment and outside the environment of the market. A further observation was aimed to obtain data on the implementation of savings and loan transactions between the green-grocers and plecitbanks in Wage Market.

Techniques of Processing and Data Analysis

The researcher carried out the data processing qualitatively. The procedures of processing the data are as follows:

1) Collecting data and archives

2) Grouping the data according to the categories

3) Associating the data with the problems

4) Checking data availability with the theme

5) Selecting the suitable data

6) Presenting and analyzing the data

\section{c. Data Analysis}

The researcher analyzed the data using the interactive model from Miles and Hubermans [8] through data reduction, data presentation and verification.

\section{RESULT AND DISCUSSION}

The lower class society such as the green-grocers in Wage Market considers plecit bank as one of their choices in having savings and loan transactions due to the fact that it has easy procedures and always exists every day in Wage market so that they do not have to come to the creditors.

Creditors are becoming more selective in providing credit. It is because the formal financial institutions have clear and compiled requirements according to the government regulations. It even worsens with the impact of the crisis that makes micro-credit provision become very difficult. This is different from the informal financial institutions such as plecit banks; when the formal financial institution is complicated by the selections of credit, this institution can provide solutions with easy credit allowances, although with a much higher interest rate than that of the formal creditors.

The middle-to-low class society, a class which frequently requires fast funds to maintain their economy, becomes the target of these informal financial institutions. Alhough these credit institutions gives a high interest rate with approximately above $20 \%$, the society remains rely on it because of its willingness to provide convenience with conditions that are also fairly easy; just in around 5-10 minutes, the money can usually be directly disbursed. This institution provides fast and easy procedures. Thus, it is more enduring as a credit institution in the society.

Historically, the informal financial institutions (plecit bank) have existed widely alongside with the formal financial institutions. When a plecit bank was initially established in Indonesia can not be identified explicitly. Nevertheless, the growth of this bank has been clearly seen and somehow this kind of bank has mingled with the economy of low-class society.

In fact, the high interest offered by the pecit banks is often brushed off by the low-class traders with relatively small capital. They often only think about how to increase revenue with the addition of venture capital.

Draft of Savings and Loan Transaction Deed between Green-grocers and Plecit Banks in Wage Market Purwokerto Are Able to Give Legal Protection

The written credit agreement, of which formulation shall be clear, take the validity and legal requirements into account and also clearly state the amount of the credit, the time period, the procedure for the payment, etc., is used to put the approved and agreed credit by both parties.

The legal protection to both parties is given by the written credit agreement. The legal protection for the weaker party, i.e. the debitor because of the capital/fund the debitor needs so bad that any conditions are approved in order that the credit can be realized. This credit agreement provides the legal protection for the debitor as he/she knows what his/her rights and obligations are, whether his/her position as partners between the debitor and the creditor has been balanced or not. Likewise, the 
creditor will also get a legal protection, especially in terms of the problem of loan repayment and legal settlement if one of the parties experience loss. The legal relationship arises between the two parties which socalled the engagement. The legal relationship is a relationship that gives rise to legal consequences guaranteed by law or acts. If one of the parties does not fulfill the rights and obligations voluntarily then the other party may prosecute it through the courts [9]

states that the credit agreement has 3 functions as follow: 1. As the principal agreement, 2. As the evidence of the limits of rights and obligations between creditors and debtors, 3. As the credit monitoring tool.

\section{CONCLUSION}

In the implementation of saving and loan transactions between the green-grocers and the plecit banks in Wage Market Purwokerto, the plecit banks (informal/illegal capital givers) have high motivation in doing their business to lend money, with easy installments (per day). However, when calculated, the amount of the interest looks quite high, surpassing the interest of legal creditors. In fact, the customers of the plecit banks have conceived the existence of plecit banks as necessary for the sake of their business persistence. It is due to their easy procedures, the fast process of cashing the loan. Besides, they also do not have either collateral or sanctions. Thus, traders heavily relied on the plecit banks.

The traders desperately need the roles of plecit banks in saving and loan transactions in Wage Market Purwokerto since the formal creditor is becoming more selective in providing credit It is because the formal financial institutions have clear and compiled requirements according to the government regulations. It even worsens with the impact of the crisis that makes micro-credit provision become very difficult. This is different from the informal financial institutions such as plecit banks; when the formal financial institution is complicated by the selections of credit, this kind of institutions can provide solutions with easy credit allowances although with a much higher interest rate than that of the creditors.

The draft of the saving and loan transactions deed between the green-grocers and the plecit banks in Wage Market Purwokerto can provide the legal protection. It is because between the creditors and debitors, they can find out the limitation of the rights and obligations. If one party violates the agreement, or it can be said tort, and the agreement can be employed as the evidence.

\section{REFERENCES}

[1] Damsar, Sosiologi Uang. Andalas University Press: Padang, 2006.

[2] Distinguin, I., Rugemintwari, C., Tacneng, R. 2016, Can informal firms hurt registered SMEs' access to credit? World Development, 84, 18-40.

[3] Djumhana, Hukum Perbankan di Indonesia, Bandung:PT Citra Aditya Bakti, 2006.

[4] Sugiyono, 2010, Memahami Penelitian Kualitatif, Bandung:Alfabeta.

[5] Suyoto, Pola dan Strategi Pembiayaan BMT dalam mendorong pertumbuhan UKM di Banyumas, Purwokerto: Universitas Muhammadiyah Purwokerto, 2010,

[6] Hidayati, Bunga, Naoyuki, yamamoto, 2017, Social Capital in Moneylenders Phenomenon in Blimbing Traditional Market Malang Indonesia, International Journal of Economics and Financial Issues | Vol 7 , Issue 3 , page $57-61$.

[7] Murwaji, Tarsisius, 2013,Penjaminan Kredit Usaha Kecil Melalui Giralisasi dan Transmisi Jaminan Kebendaan Menjadi Tunai, Jurnal Mimbar Hukum UGM, Vol.25,No.2:ISSN 0852.100N.

[8] Shoji, M. 2012, Social capital formation and credit access: Evidence from Sri Lanka. World Development, 40(12), 2522-2536.

[9] Yuan, Y., Xu, L. 2015, Are poor able to access the informal credit market? Evidence from rural households in China. China Economic Review, 33, 232-246. 